\title{
Infection levels of Austrodiplostomum compactum (Digenea, Diplostomidae) metacercariae in Plagioscion squamosissimus (Teleostei, Sciaenidae) from the Nova Avanhandava reservoir, São Paulo State, Brazil
}

\author{
J.V.K. Paes ${ }^{1 \dagger}$, E.D. Carvalho ${ }^{2 \ddagger}$ and R.J. da Silva ${ }^{3 *}$ \\ ${ }^{1}$ Pós-graduação em Ciências Biológicas (Zoologia), Instituto de \\ Biociências, Universidade Estadual Paulista (UNESP) - Botucatu, Distrito \\ de Rubião Júnior s/nº Botucatu, 18618-00 São Paulo Brazil: \\ ${ }^{2}$ Departamento de Morfologia, Instituto de Biociências, Universidade \\ Estadual Paulista, Botucatu, São Paulo, Brazil: ${ }^{3}$ Departamento de \\ Parasitologia, Instituto de Biociências, Universidade Estadual Paulista, \\ Botucatu, São Paulo, Brazil
}

(Accepted 26 August 2009; First Published Online 5 November 2009)

\begin{abstract}
This study was aimed at evaluating the infection levels of Austrodiplostomum compactum metacercariae in 378 specimens of Plagioscion squamosissimus ('corvina' or 'pescada branca') from the Nova Avanhandava reservoir, low Tietê River, São Paulo State, Brazil. High prevalence, mean intensity of infection and abundance were observed in P. squamosissimus during most of the study, with the exception of March 2004. The relative condition factor (Kn) did not differ between parasitized and non-parasitized fish. A statistically significant positive correlation was observed between host standard length and intensity of infection. The analysis of biotic and abiotic variables showed that no abiotic variable correlated with parasitic infection levels. Moreover, P. squamosissimus status was demonstrated to be unaffected by $A$. compactum metacercariae infection.
\end{abstract}

\section{Introduction}

Digenetic trematodes of the genus Austrodiplostomum Szidat \& Nani, 1951 have been reported infecting several vertebrate species (Yamaguti, 1971; Kohn et al., 1995; Ramos-Ramos, 1995). The metacercariae of these parasites can infect the vitreous humour (Scholtz et al., 1995; Silva-Souza, 1998; Amato et al., 2001) and, more rarely, the brains of the fish (intermediate hosts)

\footnotetext{
*E-mail: reinaldo@ibb.unesp.br

${ }^{\dagger}$ E-mail: jvkpaes@gmail.com

‡E-mail: carvalho@ibb.unesp.br
}

(Ostrowski-Nunez, 1982; Silva-Souza, 1998; Amato et al., 2001). The life cycle of this diplostomid is completed in the intestines of birds, such as 'biguá' Phalacrocorax olivaceus (Humboldt, 1805) (definitive host) (Rietschel \& Werding, 1978) (Ostrowski-Nunez, 1982; Ramos-Ramos, 1995; Flowers et al., 2004; Machado et al., 2005). The genus Austrodiplostomum comprises 40 digenetic helminth species, including adults and metacercariae, and can be found in 125 host species (Eiras, 1994; Niewiadomska, 1996) distributed across all continents, but most commonly in Eurasia and North America, and occasionally in South America (Niewiadomska, 1996; Niewiadomska \& Laskowski, 2002). 
Austrodiplostomum compactum (Lutz, 1928) Dubois, 1970, is widely distributed in the Neotropical region, where several fish species from Brazilian freshwater rivers are parasitized by metacercariae, including: Cichla ocellaris Bloch \& Schneider, 1801 ('tucunaré' or 'tucunaré açu'); Cichla monoculus Spix \& Agassiz, 1831 (tucunaré or tucunaré açu); Crenicichla britskii Kullander, 1982 ('joaninha'); Hoplias malabaricus (Bloch, 1794) ('traíra' or 'lobó'); Plagioscion squamosissimus (Heckel, 1840) ('corvina' or 'pescada branca'); and Satanoperca pappaterra (Heckel, 1840) ('cará', 'acará' or 'porquinho') from the Itaipu reservoir and the Upper Paraná River floodplain, State of Paraná (Kohn et al., 1995; Silva-Souza, 1998; Pavanelli et al., 2000; Santos et al., 2002; Machado et al., 2005; Yamada et al., 2007); Geophagus brasiliensis Quoy \& Gaimard, 1824 (cará or acará) from Barra Bonita (middle Tietê River, State of São Paulo) (Novaes et al., 2006); and P. squamosissimus from Nova Avanhandava, lower Tietê River, State of São Paulo (Paes et al., 2003) and from the Volta Grande reservoir,
State of Minas Gerais (Martins et al., 1999, 2002). In Venezuela, Cuba, Colombia and Mexico, other metacercariae of the genus Diplostomum have also been recorded infecting Rhamdia quelen (Quoy \& Gaimard, 1824) ('bagre' or 'jundiá'), Oreochromis aureus (Steindachner, 1864) ('tilapia' or 'tilapia azul') and Oreochromis mossambicus (Peters, 1852) (tilapia or 'tilapia de mozambique') (Pérez-Ponce de Leon et al., 1992; Garcia et al., 1993; Aragort et al., 1997; Aguirre-Macedo et al., 2001).

Plagioscion squamosissimus is a widespread fish species from the Amazonian basin. Because of its economical importance, it was introduced in the Paraná basin, mainly in great reservoirs such as Itaipu, Promissão and Marimbondo (Torloni et al., 1993; Moretto et al., 2008), where it is now the major fish product in the south-east of Brazil (Graça \& Pavanelli, 2007; Vidotto \& Carvalho, 2007).

Considering the previous occurrence of $A$. compactum metacercariae in the Tietê River (Paes et al., 2003), the aim

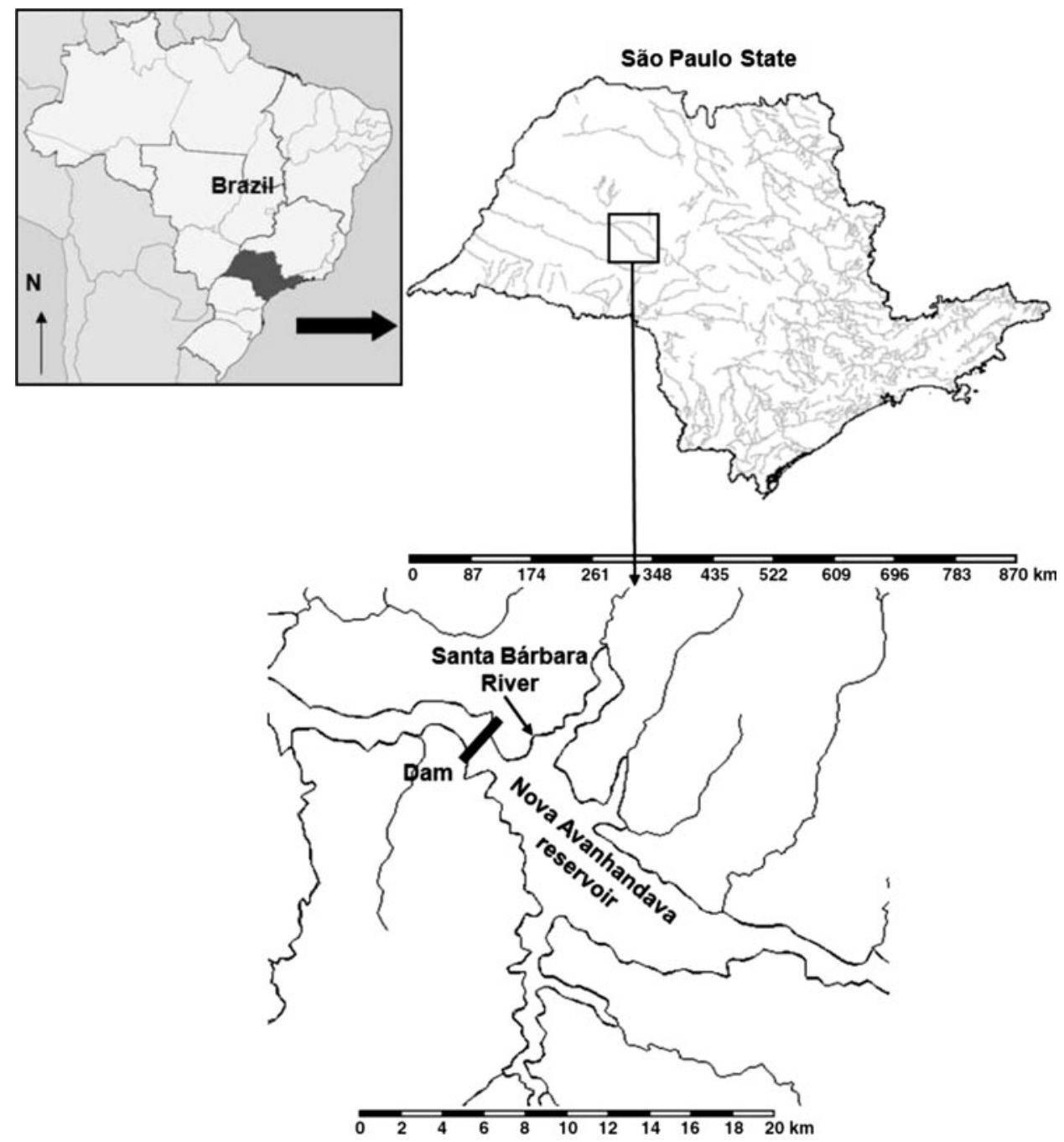

Fig. 1. Map of Brazil highlighting São Paulo State and the study area at the mouth of the Santa Bárbara River, in the Nova Avanhandava reservoir (lower Tietê River). 
of this study was to determine the prevalence, intensity of infection, abundance, seasonality and host status of A. compactum metacercariae infection. In addition, the existence of possible correlations between biotic factors (populational and parasitic) and some abiotic variables were assessed.

\section{Materials and methods}

\section{Study area and parasitological procedures}

This study was conducted in the Santa Bárbara River (municipality of Buritama, São Paulo State, Brazil), a major tributary of the Nova Avanhandava reservoir $\left(21^{\circ} 07^{\prime} \mathrm{S}\right.$ and $\left.50^{\circ} 17^{\prime} \mathrm{W}\right)$, and the penultimate of the middle Tietê River cascade of reservoirs (fig. 1). Nova Avanhandava is the second largest hydroelectric plant in operation on the Tietê River, with an installed power capacity of $347.40 \mathrm{MW}$. The reservoir has an area of $210 \mathrm{~km}^{2}$, total water volume of $2720 \times 10^{6} \mathrm{~m}^{3}$, mean discharge rate of $688 \mathrm{~m}^{3} / \mathrm{s}$, mean depth of $13 \mathrm{~m}$ and water permanence time of 46 days (Torloni et al., 1993; CESP, 1998; Rodgher et al., 2002).

Plagioscion squamosissimus specimens were collected using nylon monofilament gill nets with mesh sizes of 3-14 cm (not opposite knot lengths) from six sites on the Santa Bárbara River. Nets were placed at $17.00 \mathrm{~h}$ and removed by $07.00 \mathrm{~h}$ the following day, total exposure $14 \mathrm{~h}$, during the months of July, September, October and December of 2003 and February, March, April and June of 2004. All samples were collected from the same sites with the same network area (standardized effort $=1200 \mathrm{~m}^{2}$ of nets per month). The total weight (in grams) and standard length (distance from the anterior extremity of the head to the end of the hipural bone, in centimetres) of each specimen were recorded.

Three to six hours after collection, the eyes of all individuals were analysed under a stereomicroscope. Prevalence (number of hosts infected with one or more individuals of a particular parasite species), mean intensity of infection (mean number of parasites of a particular species found in the infected hosts of a particular species) and mean abundance (total number of individuals of a particular parasite species in a sample of a particular host divided by the total number of examined hosts of that species) were calculated according to Bush et al. (1997). Voucher helminths were deposited in the Coleção Helmintológica do Departamento de Parasitologia, Instituto de Biociências (CHIBB), Universidade Estadual Paulista, municipality of Botucatu, São Paulo State, Brazil.

\section{Data analysis}

The relative condition factor $(\mathrm{Kn})$ was employed to determine the status of $P$. squamosissimus infected by A. compactum (Andrade-Talmelli et al., 1999; Dias et al., 2004; Yamada et al., 2008). Data on the weight and length of $P$. squamosissimus specimens were pooled to establish the species weight-length relationship (LeCren, 1951). A total of 377 specimens (non-parasitized $=20$; parasitized $=357$ ) were used to determine the parameters of the equation:

$W_{\exp }=L^{b} \times a$,

where $W_{\exp }$ is the expected weight; $L$ is the fish length; $a$ is the intercept; $b$ is the slope.

Host status was assessed using the 'relative condition factor' $(\mathrm{Kn})$, estimated by dividing the observed weight of an individual by the expected weight for a given length $\left(\mathrm{Kn}=W / W_{\text {exp }}\right)$. The non-parametric Mann-Whitney statistical test was used to compare $\mathrm{Kn}$ between parasitized and non-parasitized fish. Intensity of infection in all samples was compared by the Kruskal-Wallis test, and multiple comparisons were performed by Dunn's method. Significance level was set at 5\% in all statistical analyses.

Spearman's rank correlation coefficient $\left(r_{\mathrm{s}}\right)$ was used to test the relationship between host length and intensity of infection (Abdallah et al., 2005) in order to check whether the infection process is cumulative (Takemoto et al., 2005). The distribution of mean intensity of infection according to host length in parasitized specimens was also evaluated (Sturges, 1926).

Table 1. Parasitic infection data and abiotic variables monitored by collection during the study period.

\begin{tabular}{|c|c|c|c|c|c|c|c|c|c|c|c|c|c|}
\hline \multirow[b]{2}{*}{ Date } & \multirow[b]{2}{*}{ CHIBB } & \multicolumn{6}{|c|}{ Parasitic infection data } & \multicolumn{6}{|c|}{ Abiotic variables } \\
\hline & & $N$ & $N_{\mathrm{i}}$ & $N_{\mathrm{m}}$ & $P$ & $\mathrm{MII} \pm \mathrm{SE}(R)$ & $\mathrm{MA} \pm \mathrm{SE}(R)$ & $\operatorname{Pr}$ & Tw & $\mathrm{pH}$ & $K$ & $T$ & $\mathrm{DO}$ \\
\hline Jul 03 & 511 & 31 & 30 & 635 & 96.8 & $21 \pm 5.4(1-129)$ & $20 \pm 5.2(0-129)$ & 9.2 & 0.8 & 8.3 & 154.0 & 23.4 & 7 \\
\hline Sep 03 & 512 & 55 & 53 & 1161 & 96.4 & $22 \pm 3.7(1-167)$ & $21 \pm 3.7(0-167)$ & 15.1 & 0.9 & 8.5 & 163.4 & 22.6 & \\
\hline Oct 03 & 520 & 53 & 50 & 1067 & 94.3 & $21 \pm 3.7(1-140)$ & $20 \pm 3.5(0-140)$ & 101.9 & 1.5 & 7.8 & 176.5 & 25.5 & 9 \\
\hline Dec 03 & 970 & 63 & 57 & 1124 & 90.5 & $20 \pm 3.3(1-159)$ & $18 \pm 3.2(0-159)$ & 1.0 & 1.2 & 8.5 & 149.7 & 29.0 & 7 \\
\hline Feb 04 & 459 & 75 & 73 & 1807 & 97.3 & $25 \pm 3.6(1-159)$ & $24 \pm 3.6(0-159)$ & 146.7 & 2.4 & 6.8 & 178.9 & 29.2 & 6 \\
\hline Mar 04 & 561 & 38 & 31 & 196 & 81.6 & $6 \pm 1.3(1-33)$ & $5 \pm 1.2(0-33)$ & 53.3 & 2.0 & 7.0 & 201.8 & 28.4 & 6.2 \\
\hline Apr 04 & 476 & 40 & 39 & 1275 & 97.5 & $33 \pm 7.2(1-232)$ & $32 \pm 7.1(0-232)$ & 116.6 & 2.4 & 7.2 & 203.2 & 27.2 & 6.1 \\
\hline Jun 04 & 485 & 23 & 23 & 455 & 100.0 & $20 \pm 3.4(1-55)$ & $20 \pm 3.4(1-55)$ & 39.6 & 1.4 & 8.1 & 204.2 & 22.4 & 9.0 \\
\hline
\end{tabular}

CHIBB, Coleção Helmintológica of the Departamento de Parasitologia, Instituto de Biociências, Universidade Estadual Paulista; $N$, number of collected specimens; $N_{\mathrm{i}}$, number of parasitized specimens; $N_{\mathrm{m}}$, total number of metacercariae; $P$, prevalence (\%); MII, mean infection intensity; $R$, range; $\mathrm{SE}$, standard error; MA, mean abundance; Pr, precipitation $(\mathrm{mm})$; Tw, water transparency (m); $K$, conductivity $(\mu \mathrm{S} / \mathrm{cm}) ; T$, water temperature $\left({ }^{\circ} \mathrm{C}\right) ; \mathrm{DO}$, dissolved oxygen $(\mathrm{mg} / \mathrm{l})$. 


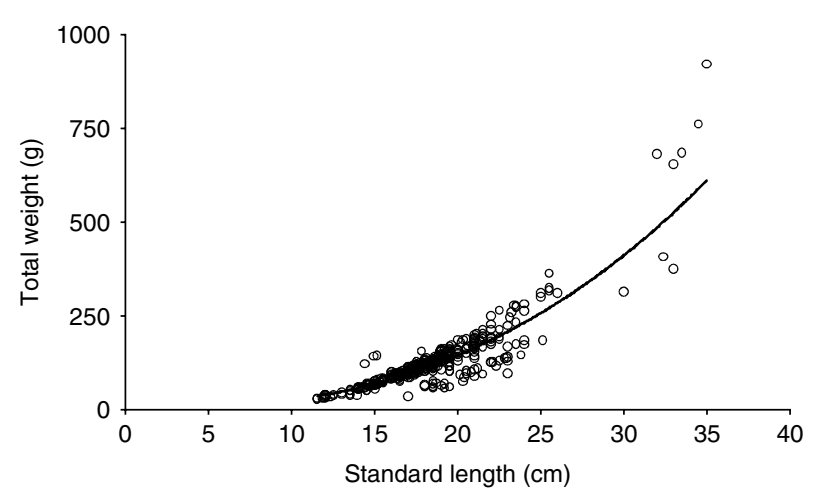

Fig. 2. Weight-length relationship in Plagioscion squamosissimus specimens $(n=377)$ captured in the study area during the study period. Equation $y=0.0649 x^{2.5732} ; R^{2}=0.8171$.

Concomitantly, Spearman's correlation test was used to check the existence of correlations between parasitic infection levels and some abiotic variables, such as accumulated monthly precipitation (data provided by the AES Tietê Company), water transparency (measured with a Secchi disk) and $\mathrm{pH}$, electrical conductivity, water temperature and dissolved oxygen, measured with Horiba U-22 (Paes, 2006).

\section{Results}

A total of 378 P. squamosissimus specimens were analysed. The mean prevalence observed was $94.3 \pm 2.1 \%$. The number of metacercariae collected ranged from 1 to 232 parasites. Mean intensity of infection and mean abundance were $21.6 \pm 1.5$ and $20.2 \pm 1.6$, respectively (table 1 ).

During the study period, the prevalence of $A$. compactum metacercariae infection remained above $90 \%$,

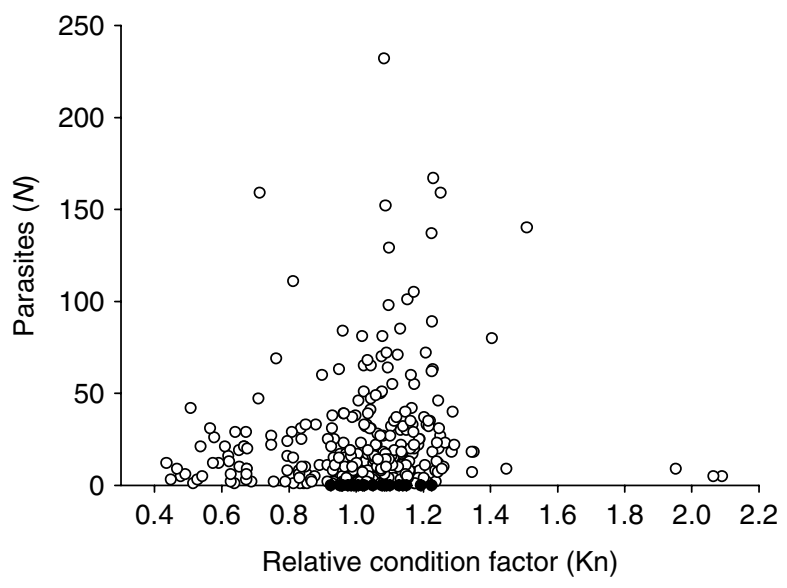

Fig. 3. Change in condition factor values (Kn) in Plagioscion squamosissimus around the 1.0 default, according to the total weight of parasitized (white circle; $n=357$ ) and non-parasitized (black circle; $n=20$ ) specimens.

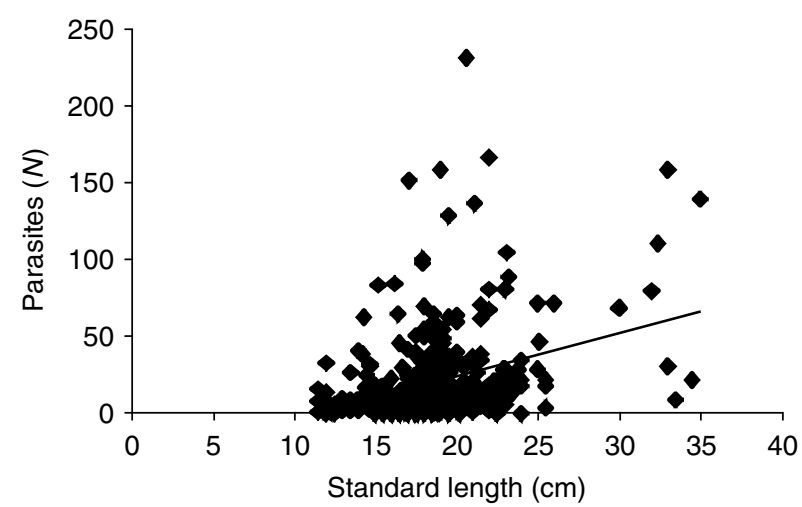

Fig. 4. Correlation between standard length and abundance of Austrodiplostomum compactum from the Nova Avanhandava reservoir, between July 2003 and June 2004. Linear regression $y=2.8292 x-32.004 ; R^{2}=0.1201$.

except in March 2004, when it was 81.6\%. Mean intensity of infection and mean abundance also showed low variation, except in March 2004, when a significant reduction in these parameters was observed $(P \leq 0.001)$ (table 1).

Host fish length and weight were $18.5 \pm 3.5$ (11.5-35) $\mathrm{cm}$ and $131.4 \pm 91.8(27.7-920.6) \mathrm{g}$, respectively. The weight-length relationship (fig. 2) was established and $\mathrm{Kn}$ was calculated for parasitized and nonparasitized specimens (fig. 3). No significant difference in $\mathrm{Kn}$ was observed between parasitized fish $(1.03 \pm 0.2$; $0.44-2.1)$ and non-parasitized fish $(1.0 \pm 0.1 ; 0.86-1.09$; $T=2913 ; P=0.068)$.

The number of parasites significantly correlated with host length $\left(r_{\mathrm{s}}=0.32, P<0.001\right)$ and host weight $\left(r_{\mathrm{s}}=0.36, P<0.001\right)$ (figs 4 and 5). Therefore, a greater intensity of infection (78 parasites/individual) was observed in the larger specimens $\left(L_{\mathrm{s}}=26.6-\right.$ $31.5 \mathrm{~cm}$ ) (fig. 6).

The analysis of biotic and abiotic variables (table 1) revealed that no abiotic variable correlated with parasitic infection level $(P>0.05)$.

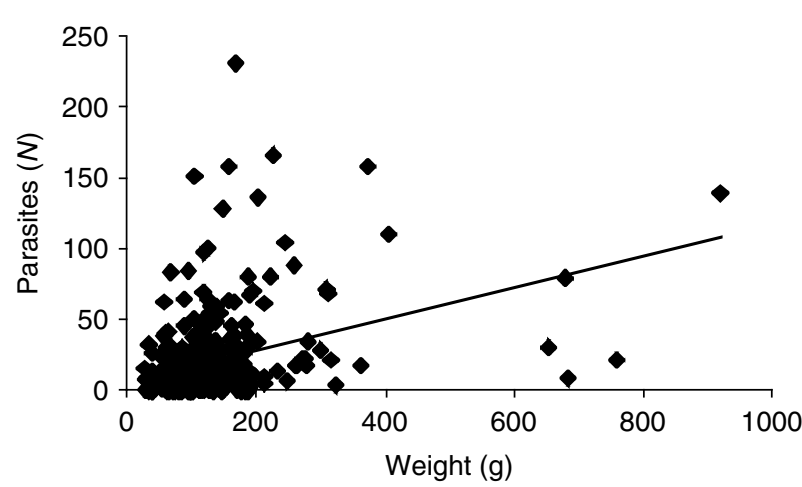

Fig. 5. Correlation between standard length and abundance of Austrodiplostomum compactum from the Nova Avanhandava reservoir, between July 2003 and June 2004. Linear regression $y=0.1114 x+5.8046 ; R^{2}=0.1264$. 


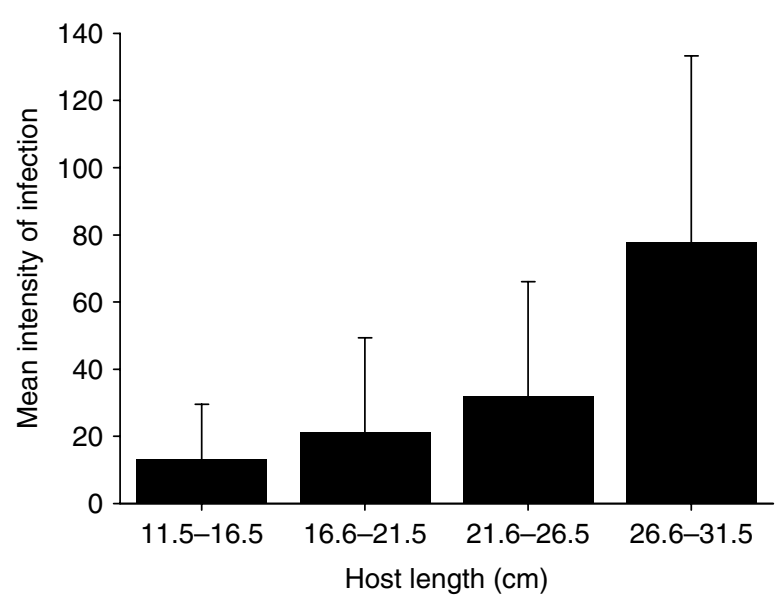

Fig. 6. Mean Austrodiplostomum compactum infection intensity and standard deviation in Plagioscion squamosissimus according to host length.

\section{Discussion}

In this study, a high prevalence of $A$. compactum metacercariae infection in $P$. squamosissimus was observed. This fish species from the Amazon Basin was introduced in São Paulo Power Company (CESP) reservoirs between 1966 and 1973 (Torloni et al., 1993). According to Pojmanska \& Chabros (1993), the prevalence of diplostomids in allochthonous fish (species from other Neotropical basins) is higher than that of autochthonous fish (species from the Upper Paraná). This was also observed by Machado et al. (2005), who found higher rates of infection in the fish introduced into the floodplain of the upper Paraná River, where P. squamosissimus species showed the highest prevalence and intensity of infection. Thus, it is possible that $A$. compactum metacercariae utilize native fish as intermediate hosts, and that their adaptation to these native hosts is the explanation for the low prevalence and intensity of infection in these fish (Machado et al., 2005).

According to Pavanelli et al. (2000), the occurrence of A. compactum metacercariae in several fish species and in different aquatic ecosystems (rivers, lakes and dams) shows that while this trematode may have been introduced with P. squamosissimus, it appears to have found appropriate ecological conditions for its parasitic cycle because, in addition to fish (second intermediate hosts), it also found snails (first intermediate hosts) (Machado et al., 2005; Ruiz \& Aguilar, 2005) and birds (definitive host) (Silva-Souza, 1998; Machado et al., 2005) in many of these ecosystems. Moreover, the low level of specificity of the metacercariae associated with the presence of intermediate hosts allows metacercariae to spread and infect other species of autochthonous fish. Specifically, in the Nova Avanhandava reservoir, the intermediate hosts, i.e. gastropod molluscs Biomphalaria glabrata (Say, 1818) and Biomphalaria intermedia (Paraense \& Deslandes, 1962) (França et al., 2007), as well as birds Phalacrocorax brasilianus (Gmelin, 1789) (Branco, 2003) and those of the genus Casmerodius (J.V.K. Paes, pers. obs.) were also observed.
The analysis of $A$. compactum infection in P. squamosissimus showed that infection levels (prevalence, mean intensity of infection and abundance) were high during most parts of the study period, with the exception of March 2004. Dörücü \& Ispir (2001), studying Diplostomum sp. metacercariae infection in Acanthobrama marmid Heckel, 1843, also noted a seasonal variation in the intensity of infection. Silva-Souza (1998) observed variation in monthly prevalence. However, rather than a clear seasonal pattern, the author found only a trend to higher A. compactum prevalence in P. squamosissimus in the driest months. These findings differ from those reported by Santos et al. (2002), who found a trend towards an increase in infection levels with the increase in precipitation and temperature.

The relative condition factor, however, did not differ significantly between parasitized and non-parasitized fish, indicating a good general fish status, irrespective of the presence of the parasite. In support of this hypothesis, studies on fish composition have shown that $P$. squamosissimus is dominant in number and biomass among the species recorded in Nova Avanhandava (Paes, 2006; Vidotto \& Carvalho, 2007). This indicates that A. compactum metacercariae parasitism does not exert a substantially negative influence on the host population. Nonetheless, lower condition factors in P. squamosissimus individuals parasitized by $A$. compactum metacercariae as compared to non-parasitized fish were observed in the Tibagi River, Paraná State by Silva-Souza (1998).

An increase in food supply might be a compensatory factor that minimizes the negative effect of parasitism. Indeed, this may have occurred in Nova Avanhandava, where $P$. squamosissimus preferably consumed aquatic insects, especially Odonata and Ephemeroptera (Vidotto, 2005) and Libelulidae and Gomphidae (Ramos et al., 2008), and shrimps (Macrobrachium sp.) (Vidotto, 2005; Ramos et al., 2008), which are very abundant in the reservoirs located on the middle and lower Tietê River (Pereira et al., 2002). In the Tibagi River, however, the main food item for this species was fish (Astyanax altiparanae Garutti \& Britski, 2000 and P. squamosissimus young) (Bennemann \& Shibatta, 2002), which require a greater effort (and tactics) to catch in comparison with shrimps and aquatic insects.

Differences in the period of introduction and establishment in ecological aquatic ecosystems, as well as different limnological features may also explain the discrepancy between $P$. squamosissimus data obtained in the Tibagi River (Silva-Souza, 1998) and those found in the present study in Nova Avanhandava (Bittencourt-Oliveira, 2002; Shibatta et al., 2002; Yabe \& Gimenez, 2002; Paes, 2006; Vidotto \& Carvalho, 2007). According to some reports, P. squamosissimus was equivocally introduced in the Tietê River during the 1960s (Torloni et al., 1993), while in the Tibagi River, Paraná State, it was introduced more recently, in the early 1990s (Bennemann \& Shibatta, 2002). This information suggests that the longer the time of $A$. compactum metacercariae interaction with $P$. squamosissimus, the smaller the negative effects on the host.

In this study, the significant correlation found between the length of parasitized specimens and mean intensity of infection indicates that $A$. compactum metacercariae 
infection is a cumulative process. Aragort et al. (1997) also found a positive correlation between length and intensity of infection in a study of the parasitic fauna in tilapia (O. mossambicus and O. aureus) of the Valencia Lake (Venezuela). They observed that intensity of infection was higher in the larger fish (in weight), and suggested that the relationship between intensity of infection and length might be due to the fact that larger specimens have a greater body surface for infection. The present study and that of Aragort et al. (1997) corroborate the island biogeography theory (Kuris et al., 1980).

Austrodiplostomum compactum metacercariae most commonly parasitize the vitreous humour, but some metacercariae can also be found in the aqueous humour (Garcia et al., 1993) and the brain of their hosts (Ostrowski-Nunez, 1982; Conroy et al., 1985; PinedaLópez, 1985; Osorio-Sarabia et al., 1987; Silva-Souza, 1998). In this study, however, although the brains or other organs of the specimens were not examined, only free metacercariae were found in the vitreous humour, and no eye lesions were observed macroscopically.

According to Martins (1998), digenetic trematodes are more pathogenic when a fish is acting as an intermediate host because the parasite is more aggressive to the host at this metacercaria stage than in its adult forms. Migration to the host tissues in order to reach other infection sites (eyes, brain, among others) can cause injury and, if encysted, tissue changes. The fact that metacercariae cause diseases and weaken hosts is an important ecological characteristic. Weakened fish can be easily preyed and, as a consequence, the parasite cycle can be completed in the predator (bird), the definitive host (Pavanelli et al., 2006).

Evans et al. (1976) and Eiras (1994) showed that, depending on host size, 40 metacercariae/eye may cause blindness, cataracts or undermined vision. Garcia et al. (1993) found that the presence of $A$. compactum metacercariae in the eyes (aqueous and vitreous humour) and brain of tilapia $O$. aureus and O. mossambicus from the Amela Lake in Colima (Mexico) caused injuries in the cornea and conjunctiva. Silva-Souza (1998) did not find any injury or inflammatory reaction resulting from infection in $P$. squamosissimus. The same (no damage, cataracts or blindness) was observed in this study despite the record of up to 136 metacercariae in a single eyeball. It is noteworthy that metacercariae of other species of the Diplostomidae family have caused mortality and decreases in condition factors in catfish Ictalurus punctatus (Rafinesque, 1818) at fish farms in the USA (Overstreet \& Curran, 2004).

\section{Acknowledgements}

The authors are thankful to Laboratório de Biologia e Ecologia de Peixes and Laboratório de Parasitologia de Animais Silvestres (Universidade Estadual Paulista, UNESP - Instituto de Biociências - IB, Campus de Botucatu, São Paulo, Brazil), for the use of their facilities during the conduction of this research; the Post-Graduate Course in Biological Sciences (Zoology) for their support during every stage of this work; Dr Ana Paula Vidotto and Dr José Luís Costa Novaes (Departamento de Morfologia, IB, UNESP) for their help in the critical reading of the manuscript; Ricardo A. S. Teixeira, Renato Devidé (Departamento de Morfologia, IB, UNESP) and Dr Karina Rodrigues dos Santos (Departamento de Parasitologia, IB, UNESP, Botucatu) for their help in the field and laboratory work; Conselho Nacional de Desenvolvimento Científico e Tecnológico - CNPq (process n. 133203/2004-2 and 140838/2007-4), Fundação Paulista de Amparo a Pesquisa - FAPESP (process n. 03/11 239-2) and Fundação para o Desenvolvimento da Unesp - FUNDUNESP (process n. 00329/04) for their financial support. This work complies with current Brazilian laws.

\section{References}

Abdallah, V.D., Azevedo, R.K. \& Luque, J.L. (2005) Ecologia da comunidade de metazoários parasitos do sairú Cyphocarax gilbert (Quoy e Gaimard, 1824) (Characiformes: Curimatidae) do rio Guandu, Estado do Rio de Janeiro, Brasil. Revista Brasileira de Parasitologia Veterinária 14, 154-159.

Aguirre-Macedo, M.L., Scholz, T., González-Solís, D., Vidal-Martinez, V.M., Posel, P., Arjona-Torres, G., Siu-Estrada, E. \& Dumailo, S. (2001) Larval helminths parasitizing freshwater fishes from the Atlantic Coast of Nicarágua. Comparative Parasitology 68, 42-51.

Amato, S.B., Amato, J.F.R. \& Albrecht, M. (2001) Metacercárias livres de diplostomídeos (Digenea, Diplostomidae) em Loricariichthys anus (Val., 1840) (Siluriformes, Loricariidae) do Estado do Rio Grande do Sul, Brasil. Parasitología al día 25, 1-7.

Andrade-Talmelli, E.F., Fenerich-Verani, N. \& Verani, J.R. (1999) Fator de condição relativo (Kn): um critério para selecionar fêmeas de Piabinha, Brycon insignis (Steindachner, 1876) (Pisces: Bryconinae), para indução reprodutiva. Boletim do Instituto de Pesca de São Paulo 25, 95-99.

Aragort, F.W., Leon, E.A., Guillén, A.T., Silva, M. \& Balestrini, C. (1997) Fauna parasitaria em tilapias del Lago de Valencia. Veterinaria Tropical 22, 171-187.

Bennemann, S.T. \& Shibatta, A.O. (2002) Dinâmica de uma assembléia de peixes do rio Tibagi. pp. 433-442 in Medri, M.E., Bianchini, E., Shibatta, A.O. \& Pimenta, J.A. (Eds) A bacia do rio Tibagi. Londrina, UEL.

Bittencourt-Oliveira, M.C. (2002) A comunidade fitoplanctônica do rio Tibagi: uma abordagem preliminar de sua diversidade. pp. 373-402 in Medri, M.E. Bianchini, E., Shibatta, A.O. \& Pimenta, J.A. (Eds) A bacia do rio Tibagi. Londrina, UEL.

Branco, M.B.C. (2003) Diversidade da avifauna aquatic nas represas do Médio e Baixo Rio Tietê (SP) e no sistema de lagos do Médio Rio Doce (MG) e sua relação com o estado trófico e a morfometria dos ecossistemas aquáticos Masters dissertation, Universidade Federal de São Carlos - UFSCar, São Carlos (SP).

Bush, A.O., Lafferty, K.D., Lotz, J.M. \& Shostak, A.W. (1997) Parasitology meets ecology on its own terms: Margolis revisited. The Journal of Parasitology 83, 575-583. 
CESP (Companhia Energética de São Paulo) (1998) Conservação e manejo nos reservatórios: limnologia, ictiologia e pesca. Série Divulgação e informação. São Paulo, CESP.

Conroy, G., Conroy, D.A., Santacana, J.A. \& Perdomo, F. (1985) Diplostomatosis in cultured Venezuelan grey mullets. Bulletin of the European Association of Fish Pathologists 5, 14-16.

Dias, P.G., Furuya, W.M., Pavanelli, G.C., Machado, M.H. \& Takemoto, R.M. (2004) Carga parasitária de Rondonia rondoni Travassos, 1920 (Nematoda, Atrictidae) e fator de condição do armado, Pterodoras granulosus, Valenciennes, 1833 (Pisces, Doradidae). Acta Scientiarum Biology Science 26, 151-156.

Dörücü, M. \& Íspir, Ü. (2001) Seasonal variation of Diplostomum sp. infection in eyes of Acanthobrama marmid Heckel, 1843 in Keban Dam Lake, Elaziğ, Turkey. E.U. Journal of Fisheries and Aquatic Sciences 18, 301-305.

Eiras, J.C. (1994) Elementos de Ictioparasitologia. 339 pp. Porto, Fundação Engenheiro Antônio de Almeida.

Evans, R.S., Heckmann, R.A. \& Palmieri, J. (1976) Diplostomiasis in Utah. Utah Academy Proceedings 53, 20-25.

Flowers, J.R., Poore, M.F., Mullen, J.E. \& Levy, M.G. (2004) Digeneans collected from piscivorous birds in North Carolina, USA. Comparative Parasitology 71, 243-244.

França, R.S., Suriani, A.L. \& Rocha, O. (2007) Composição das espécies de moluscos bentônicos nos reservatórios do baixo rio Tietê (São Paulo, Brasil) com uma avaliação do impacto causado pelas espécies exóticas invasoras. Revista Brasileira de Zoologia 24, 41-51.

Garcia, M.L.J., Osório-Sarabia, D. \& Constantino, F. (1993) Prevalência de los parasitos y lãs alteraciones histológicas que producen a las tilapias de la laguna de Amela Tecoman Colima. Veterinaria México 24, 199-205.

Graça, W.J. \& Pavanelli, C.S. (2007) Peixes da planície de inundação do alto rio Paraná e áreas adjacentes. 241 pp. Maringá, EDUEM.

Kohn, A., Fernandes, B.M.M. \& Baptista-Farias, M.F.D. (1995) Metacercariae of Diplostomum (Austrodiplostomum) compactum (Trematoda, Diplostomidae) in the eyes of Plagioscion squamosissimus (Teleostei, Sciaenidae) from the reservoir of the Hydroelectric Power Station of Itaipu, Brazil. Memórias do Instituto Oswaldo Cruz 90, 341-344.

Kuris, A.M., Blaustein, A.R. \& Alió, J.J. (1980) Hosts as islands. The American Naturalist 116, 570-586.

LeCren, E.D. (1951) The length-weight relationship and seasonal cycle in gonad weight and condition in perch Perca fluviatilis. The Journal of Animal Ecology 20, 201-219.

Machado, P.M., Takemoto, R.M. \& Pavanelli, G.C. (2005) Diplostomum (Austrodiplostomum) compactum (Lutz, 1928) (Platyhelminthes, Digenea) metacercariae in fish from the floodplain of the Upper Paraná River, Brazil. Parasitology Research 97, 436-444.

Martins, M.L. (1998) Doenças infecciosas e parasitárias de peixes. Jaboticabal, Boletim Técnico do Centro de Aqüicultura da UNESP.
Martins, M.L., Fujimoto, R.Y., Nascimento, A.A. \& Moraes, F.R. (1999) Ocorrência de Diplostomum sp. Nordmann, 1832 (Digenea: Diplostomidae) em Plagioscion squamosissimus (Heckel, 1840) proveniente do reservatório de Volta Grande, MG, Brasil. Acta Scientiarum 21, 263-266.

Martins, M.L., Paiva, A.M.F.C., Fujimoto, R.Y., Schalch, S.H.C. \& Colombano, N.C. (2002) Prevalência, sazonalidade e intensidade de infecção por Diplostomum (Austrodiplostomum) compactum Lutz, 1928 (Digenea, Diplostomidae), em peixes do reservatório de Volta Grande, Estado de Minas Gerais, Brasil. Acta Scientiarum 24, 469-474.

Moretto, E.M., Marciano, F.T., Velludo, M.R., Fenerich-Verani, N., Espindola, E.L.G. \& Rocha, O. (2008) The recent occurrence, establishment and potential impact of Geophagus proximus (Cichlidae: Perciformes) in the Tietê river reservoirs: an Amazonian fish species introduced in the Paraná Basin (Brazil). Biodiversity and Conservation 17, 3013-3025.

Niewiadomska, K. (1996) The genus Diplostomum taxonomy, morphology and biology. Acta Parasitologica 41, 55-66.

Niewiadomska, K. \& Laskowski, Z. (2002) Systematic relationships among six species of Diplostomum Nordmann, 1832 (Digenea) based on morphological and molecular data. Acta Parasitologica 47, 20-28.

Novaes, J.C.L., Ramos, I.P., Carvalho, E.D. \& Silva, R.J. (2006) Metacercariae of Diplostomum compactum Lutz, 1928 (Trematoda, Diplostomidae) in the eyes of acara Geophagus brasiliensis Quoy \& Gaimard, 1824 (Teleostei, Cichlidae) from Barra Bonita Reservoir - São Paulo, Brazil. Arquivo Brasileiro de Medicina Veterinária e Zootecnia 58, 1229-1231.

Osorio-Sarabia, V., Pineda-López, R. \& SalgadoMaldonado, G. (1987) Fauna helmintológica de peces dulceacuícolas de Tabasco. Estudio preliminar. Universidad y Ciência 4, 5-31.

Ostrowski-Nunez, M. (1982) The life histories of Diplostomum (Austrodiplostomum) compactum (Lutz, 1928) Dubois, 1970 and D. (A.) mordax (Szidat and Nani, 1951) n. comb. in South América. Zoologischer Anzeiger 208, 393-404.

Overstreet, R.M. \& Curran, S.S. (2004) Defeating diplostomoid dangers in USA catfish aquaculture. Folia Parasitologica 51, 153-165.

Paes, J.V.K. (2006) A ictiofauna associada e as condições limnológicas num sistema de piscicultura em tanquesrede no reservatório de Nova Avanhandava (baixo Rio Tietê, SP). Masters dissertation, Universidade Estadual Paulista - UNESP, Botucatu (SP).

Paes, J.V.K., Santos, K.R., Carvalho, E.D. \& Silva, R.J. (2003) Ocorrência de metacercária de Diplostomum compactum (Trematoda, Diplostomidae) parasitando Plagioscion squamosissimus (Teleostei, Sciaenidae) proveniente do reservatório de Nova Avanhandava, Buritama, São Paulo. Arquivos do Instituto Biológico 70, 383-387.

Pavanelli, G.C., Takemoto, R.M., Machado, P.M., Lizama, M.A.P., Tanaka, L.K., Guidelli, G.M., Issac, A., Carvalho, S. \& França, J.G. (2000) A planície alagável do Alto Rio Paraná: estrutura e processos ambientais. 
Componentes biológicos: ictioparasitologia. Programa PELD/CNPQ.

Pavanelli, G.C., Takemoto, R.M., Lizama, M.A.P., Guidelli, G.M., Lacerda, A.C.F., Yamada, F.H., Tavernari, F.C., Moreira, L.H.A., Ceschini, T.L., Bellay, S. \& Fernandes, E.S. (2006) A planície de inundação do alto rio Paraná: Ictioparasitologia. Programa PELD/CNPQ.

Pereira, C.C.G.F., Smith, W.S., Espíndola, E.L.G. \& Rocha, O. (2002) Alterações tróficas nas espécies de peixes em decorrência da construção de reservatórios em cascata no médio e baixo rio Tietê. pp. 29-41 in PPG - CEA. Recursos Hidroenergéticos: Usos, Impactos e Planejamento Integrado. São Carlos, Rima Editora.

Pérez-Ponce de Leon, G., Osório-Saraiba, D. \& GarciaPrieto, L. (1992) Helmintofauna del 'Juile' Rhamdia guatemalensis (Pisces: Pimelodidae), del lago de Catemaco, Veracruz. Revista da Sociedade Mexicana de História Natural 43, 25-31.

Pineda-López, R. (1985) Infección por metacercárias (Plathyhelminthes: Trematoda) em peces de agua dulce de Tabasco. Universidad y Ciência 2, 47-60.

Pojmanska, T. \& Chabros, M. (1993) Parasites of common carp and three introduced cyprinid fish in pound culture. Acta Parasitologica 38, 101-108.

Ramos, I.P., Vidotto-Magnoni, A.P. \& Carvalho, E.D. (2008) Influence of cage fish farming on the diet of dominant fish species of a Brazilian reservoir (Tietê River, High Paraná River Basin). Acta Limnologica Brasiliensia 20, 245-252.

Ramos-Ramos, P. (1995) Algunos trematodos de vertebrados de la presa Miguel Aleman em Temascal, Oaxaca, México. Anales del Instituto de Biologia, Serie Zoologia 66, 241-246.

Rietschel, G. \& Werding, B. (1978) Trematodes of birds from Northern Columbia. Zeitschrift für Parasitenkunde 57, 57-82.

Rodgher, S., Espíndola, E.L.G., Fracácio, R., Rodrigues, M.H., Pereira, R.H.G. \& Rocha, O. (2002) Estudos ecotoxicológicos nos reservatórios em cascata do médio e baixo rio Tietê: uma avaliação dos impactos ambientais. pp. 131-144 in PPG - CEA. Recursos Hidroenergéticos: Usos, Impactos e Planejamento Integrado. São Carlos, Rima Editora.

Ruiz, L.J.R. \& Aguilar, J.G. (2005) Estructura de la comunidad y dinámica poblacional de gasterópodos em una zona enzoótica de fasciolosis en Tabasco, México. Acta Zoologica Mexicana 21, 79-85.

Santos, R.S., Pimenta, F.D.A., Martins, M.L., Takahashi, H.K. \& Marengoni, N.G. (2002) Metacercárias de Diplostomum (Austrodiplostomum) compactum Lutz, 1928 (Digenea, Diplostomidae) em peixes do rio Paraná, Brasil, Prevalência, sazonalidade e intensidade de infecção. Acta Scientiarum 24, 475-480.

Scholtz, T., Vargas-Vázquez, J., Moravec, F., VivasRodríguez, C. \& Mendonza-Franco, E. (1995) Metacercariae of trematodes of fishes from cenotes (=sinkholes) of the Yucatan Península, México. Folia Parasitologica 42, 173-192.

Shibatta, O.A., Orsi, M.L., Bennemann, S.T. \& Silva-Souza, A.T. (2002) Diversidade e distribuição de peixes na bacia do rio Tibagi. pp. 403-423 in Medri, M.E., Bianchini, E., Shibatta, A.O. \& Pimenta, J.A. (Eds) A bacia do rio Tibagi. Londrina, Universidade Estadual de Londrina.

Silva-Souza, A.T. (1998) Estudo do parasitismo de Plagioscion squamosissimus (Heckel 1940) (Perciformes, Sciaenidae) por Diplostomum (Austrodiplostomum) compactum (Lutz, 1928) (Trematoda, Digenea) no rio Tibagi, PR. PhD Thesis, UFSCar, São Carlos.

Sturges, H.A. (1926) The choice of a class interval. Journal of the American Statistical Association 21, 65-66.

Takemoto, R.M., Lizama, M.A.P., Guidelli, G.M., Pavanelli, G.C., Moreira, S.T., Ito, K.F., Lacerda, A.C.F. \& Bellay, S. (2005) Fauna parasitária de peixes em reservatórios. pp. 269-280 in Rodrigues, L., Thomaz, S.M., Agostinho, A.A. \& Gomes, L.C. (Eds) Biocenoses em reservatórios: padrões espaciais e temporais. São Carlos, Rima Editora.

Torloni, C.E.C., Corrêa, A.R.A., Carvalho, A.A. Jr, Santos, J.J., Gonçalves, J.L., Gereto, E.J., Cruz, J.A., Moreira, J.A., Silva, D.C., Deus, E.F. \& Ferreira, A.S. (1993) Produção pesqueira e composição das capturas em reservatórios sob concessão da CESP nos rios Tietê, Paraná e Grande, no período de 1986 a 1991.73 pp. Série pesquisa e desenvolvimento No. 1. São Paulo, CESP.

Vidotto, A.P. (2005) Estrutura da comunidade de peixes do reservatório de Nova Avanhandava (baixo rio Tietê $\mathrm{SP})$, com ênfase na dinâmica populacional e dieta das espécies introduzidas. Masters dissertation, Universidade Estadual Paulista - UNESP, Botucatu (SP).

Vidotto, A.P. \& Carvalho, E.D. (2007) Composition and structure of fish community in a stretch of the Santa Bárbara River influenced by Nova Avanhandava Reservoir (low Tietê River, São Paulo State, Brazil). Acta Limnologica Brasiliensia 19, 233-245.

Yabe, M.J.S. \& Gimenez, S.M.N. (2002) Caracterização fisico-química da água da bacia do rio Tibagi. pp. 355-371 in Medri, M.E., Bianchini, E., Shibatta, A.O. \& Pimenta, J.A. (Eds) A bacia do rio Tibagi. Londrina, UEL.

Yamada, F.H., Takemoto, R.M. \& Pavanelli, G.C. (2007) Ecological aspects of ectoparasites from the giils of Satanoperca pappaterra (Heckel, 1840) (Cichlidae) from the upper Paraná river floodplain, Brazil. Acta Scientiarum Biology Science 29, 331-336.

Yamada, F.H., Moreira, L.H.A., Ceschini, T.L., Takemoto, R.M. \& Pavanelli, G.C. (2008) Novas ocorrências de metacercárias de Austrodiplostomum compactum (Lutz, 1928) (Platyhelminthes: Digenea) parasito de olhos de peixes da bacia do rio Paraná. Revista Brasileira de Parasitologia Veterinária 17, 163-166.

Yamaguti, S. (1971) Synopsis of Digenetic Trematodes of Vertebrates. Vol. II. 1074 pp. Tokyo, Keigaku Publishing Company. 